Eugenio Coseriu 



\section{Eugenio Coseriu}

Past, Present and Future

Edited by

Klaas Willems and Cristinel Munteanu 
This publication was printed with the financial support of “Danubius” University of Galați (Romania) and the Linguistics Department of Ghent University (Belgium).

ISBN 978-3-11-071233-9

e-ISBN (PDF) 978-3-11-071239-1

e-ISBN (EPUB) 978-3-11-071241-4

Library of Congress Control Number: 2021937869

Bibliographic information published by the Deutsche Nationalbibliothek

The Deutsche Nationalbibliothek lists this publication in the Deutsche Nationalbibliografie; detailed bibliographic data are available on the Internet at http://dnb.dnb.de

(c) 2021 Walter de Gruyter GmbH, Berlin/Boston

Cover illustration: photo Coseriu in younger years: @ 2021 Eugenio Coseriu-Archiv Tübingen; photo Coseriu in later years: Universiteitsarchief Gent, @ UGent, foto Hilde Christiaens;

logo: (c) 2021 Eugenio Coseriu-Archiv Tübingen

Printing and binding: $\mathrm{CPI}$ books $\mathrm{GmbH}$, Leck

www.degruyter.com 